\title{
Enlightenment and Change
}


The New History of Scotland Series Editor: Jenny Wormald

Original titles in the New History of Scotland series were published in the 1980s and re-issued in the 1990s. This popular and enduring series is now being updated with the following published and forthcoming titles:

Kingship and Unity: Scotland 1000-1306

G. W. S. Barrow

Court, Kirk and Community: Scotland 1470-1625

(second revised and updated edition)

Jenny Wormald

Crown, Covenant and Union: Scotland 1625-1763

Alexander Murdoch

Enlightenment and Change: Scotland 1746-1832

(second revised and updated edition of Integration and

Enlightenment)

Bruce P. Lenman

Ourselves and Others: Scotland 1832-1914

Graeme Morton 


\section{Enlightenment and Change Scotland 1746-1832}

Bruce P. Lenman

Edinburgh University Press 
(C) Bruce P. Lenman, 2009

Revised and updated edition. First published in 1981 as

Integration, Enlightenment, and Industrialization: Scotland 1746-1832

by Edward Arnold (Publishers) Ltd

Reprinted in 1992 as Integration and Enlightenment

by Edinburgh University Press

Edinburgh University Press Ltd

22 George Square, Edinburgh

www.euppublishing.com

Typeset in 10.5/13pt Sabon

by Servis Filmsetting Ltd, Stockport, Cheshire, and

printed and bound in Great Britain by

CPI Antony Rowe, Chippenham and Eastbourne

A CIP record for this book is available from the British Library

ISBN 9780748625147 (hardback)

ISBN 9780748625154 (paperback)

The right of Bruce P. Lenman to be identified as author of this work has been asserted in accordance with the Copyright, Designs and Patents Act 1988. 